Nowoczesne Systemy Zarządzania

Zeszyt 15 (2020), nr 3 (lipiec-wrzesień)

ISSN 1896-9380, s. 39-50

DOI: $10.37055 / \mathrm{nsz} / 132940$

Modern Management Systems

Volume 15 (2020), No. 3 (July-September)

ISSN 1896-9380, pp. 39-50

DOI: $10.37055 / \mathrm{nsz} / 132940$
Instytut Organizacji i Zarządzania Wydział Bezpieczeństwa, Logistyki i Zarządzania

Wojskowa Akademia Techniczna

w Warszawie

Institute of Organization and Management Faculty of Security, Logistics and Management Military University of Technology

\title{
Design-Based Thinking Method in Business Management
}

\section{Metoda design-based thinking w zarządzaniu przedsiębiorstwem}

\author{
Daiva Žostautienè \\ Kaunas University of Technology, Lithuania \\ daiva.zostautiene@ktu.It, ORCID: 0000-0003-0344-2886 \\ Dalia Susnienè \\ Kaunas University of Technology, Lithuania \\ dalia.susniene@ktu.It, ORCID: 0000-0003-1639-7180 \\ Daina Mekiene \\ UAB Izabelita, Lithuania \\ info@izabelita.It
}

\begin{abstract}
Rapid technological development, geographically unrestricted markets, offer customers great opportunities to meet their needs when choosing and purchasing products or services, and companies need to use new and creative methods such as design-based thinking to identify consumer expectations and create a product or service that meets consumer needs. The aim of this article is to present the method of design-based thinking and its application in managing the company. The methods of analysis and synthesis the scientific literature used revealed that design-based thinking can help to create added value by using the company's available resources and improving existing processes at all levels of the company. Keywords: design-based thinking, business management
\end{abstract}

Abstrakt. Szybki rozwój technologiczny, geograficznie nieograniczone rynki oferują klientom ogromne możliwości zaspokojenia ich potrzeb przy wyborze i zakupie produktów lub usług, a firmy muszą korzystać z nowych i kreatywnych metod, takich jak design-based thinking, aby zidentyfikować oczekiwania konsumentów i stworzyć produkt lub usługę, które spełnią ich potrzeby. Celem artykułu jest przedstawienie metody design-based thinking i jej zastosowania w zarządzaniu przedsiębiorstwem. 
Metody analizy i syntezy literatury przedmiotu wykazały, że design-based thinking może przyczynić się do powstania wartości dodanej poprzez wykorzystanie dostępnych zasobów firmy i poprawę istniejących procesów na wszystkich poziomach zarządzania przedsiębiorstwem.

Słowa kluczowe: design-based thinking, zarządzanie przedsiębiorstwem

\section{Introduction}

Design-based thinking is used to develop new business models, events, job role definitions, recruitment processes, strategies, curricula, internal processes (Schmiedgen, Rhinow, Köppen, Meinel, 2015). The design-based thinking method which can be described as a creative thinking process is believed to stimulate out-of-the-box thinking and contribute to innovation in an organization. The concept of design-based thinking is new, and the broad application of the method creates the need for a better understanding of the essence of the design-based approach. Therefore, the article aims to reveal the concept of design-based thinking and its application possibilities. The first part specifically focus to reveal the concept of design-based thinking and gives an overview of the development of the concept implementation in the EU countries? Next, the elements and process of design-based thinking are presented and finally, the possibilities of applying the design-based thinking method in business are presented.

\section{The concept of design-based thinking}

Although the term is new and now fashionable, the way of thinking is not new. The emergence of the term dates back to the 1960s, when the aim was to find out the purpose of designers' activities and what their thinking was in order to solve complex problems. The emergence of design-based thinking has raised questions: is it a new way of designing itself, or is it a new way of working for non-design companies? Does design-based thinking offer anything new compared to other innovations related to creativity and consumerism? In the 1960s, research began to elucidate what design is, how a process could have been created and activities improved, and so the academic roots of design-based thinking stem from this period. The conceptual understanding of design-based thinking is the creation of added value by using the resources available to the company and improving the existing processes at all levels of the company.

The definition of design-based thinking is not uniform, the interpretation differs (Carlgren et al., 2016; Glen et al., 2015), because in order to make concrete the concept of design-based thinking, practitioners were usually approached rather than scientists, so there is lack of theoretical basis. The word "design" itself has several meanings and is difficult to define due to application practices ranging from the work 
of professional designers to the design tasks that people face on a daily basis. Martin (2009) and Verganti (2003) focus on creating sustainable innovation through a design-based approach to thinking. From an academic point of view, design-based thinking can be seen as a methodology for actualizing concepts and ideas (Cohen, 2014).

In practice, design-based thinking is seen as an innovation methodology because it is both a process and a problem-solving and business value creation. Design-based thinking is a methodology for creating innovations that incorporates human, technological, and business elements in shaping, designing, and solving a problem (Plattner, Meinel, Leifer, 2010). It is a process during which new products, services and systems are produced through interdisciplinary cooperation in design, engineering, business. In this context, innovation management can be understood as the management of innovation processes in terms of both product and organizational innovation. Unlike linear methods of innovation, the design-based approach of thinking is not a rigorous process, but a system that integrates creative and analytical reasoning, certain approaches, as well as a variety of practical tools and methods. Important aspects in design-based thinking are: identifying problems, determining the level of the problem, shaping the value of the company and the competitive advantage of the product or service it creates through process management. H.A. Simon (1969) proposed design as an approach to "making existing conditions the most appropriate", which is a different approach from the prevailing decision-making practice that relies primarily on analytical (i.e., deductive and inductive) thinking and seeks consistent and predictable results (Martin, 2009). Design-based thinking creates innovation, examines the challenges of innovation, and questions previous ways of creating value in order to comprehensively address a problem in a complex market context. This method first changes the value attributed by consumers to the product, but not the functional changes in the product. By creating new concepts, streamlining the process to reduce costs, streamline product function, or redesign business practices, designers create new experiences, add value, and open up new markets (Heskett, Dilnot, Boztepe, 2017). Flexible in nature, design-based thinking expands its meanings, definitions, and relationships by integrating business and human factors, combining the latest technologies, digital experiences, environments, creating new solutions and enabling deeper emotional connections with brands the consumer chooses to embrace into your life (Martin, 2009).

Design-based thinking is based on the identification of problems by researching consumer and company problems, applying appropriate research methods. Problem solving at the conceptual level must be shaped by managing consumer expectations and needs as well as managing business processes while maintaining resources and creating added value. The wide application of design creates the need for a better understanding of the thinking on which design is based. It is particularly important that this method can be used to identify problems, but the most valuable thing is to overcome them, so creativity is essential to design-based thinking. 
Creative people tend to work in two different ways: as inventors and as creators (Owen, 2007). The creativity of inventors is manifested in understanding and finding explanations for ambiguous things. Developers are just as creative, but they are forced to apply what they know in new designs, models, and concepts. Given the fundamental differences between how inventors and creators think and work, other factors may also reveal differences between professional domains and may therefore help to define the concept of design-based thinking.

To take advantage of this approach, a company should understand the differences between analytical and design-based thinking and why misunderstandings can arise. Unlike analytical thinking, which is a process of analysis and involves the deconstruction of ideas, design-based thinking is a creative process based on the creation of ideas and removes the fear of failure, welcomes unusual ideas that often pave the way for the most creative decisions. This approach not only makes it possible to regulate the actual problems that companies may face, but also, and most importantly, to create a preferred scenario for future development - different design-based thinking models make innovation processes more comprehensive by focusing on designing new opportunities rather than choosing alternatives. When design-based thinking, as transformation, is seen as the widest possible competence, it is applied to the entire value creation process: to create product, service, company value, thus gaining a competitive advantage (Krippendorff, 2006). The use of a design-based approach to thinking allows you to develop a pragmatic and insightful approach to name development, labeling, mission and vision, product value, and more. The former open system is integrated into a coherent system with value creation for all stakeholders - from users to members of the development team. Companies that use design as a key element of their strategy are much more likely to innovate.

\section{Developments in the implementation of the concept of design-based thinking in Lithuania}

The methodology of design-based thinking was introduced in business development. The transition to co-design and interdisciplinary teams has focused on opening up internal creative processes and ways of thinking to make them more transparent and usable by all.

The large global corporations like Google, Samsung and IBM have already applied design-based thinking in their activities and thus create value for the consumer and contribute to increasing competitiveness, leading to the transformation of the values of products and services, their constant updating.

Design Thinking method was first included in the European Innovation Strategy in 2010. This year (2020), the European Commission published a Communication 
on the Europe 2020 Strategy, a flagship initiative of the Innovation Union, which envisages design as a strategic tool to add value and reflect Europe's strengths. This has fundamentally changed the way European design strategy is shaped. In 2011 European Design Council has set up on the initiative of the European Commission to increase the role of design in innovation policy. In 2013 a document entitled 'Implementing the Action Plan for Promoting Design-Based Innovation' was announced, which emphasized the promotion of design-based innovation in industries to strengthen European competitiveness and design-based public sector renewal (https://ec.europa.eu/growth/tools-databases/regional-innovation-monitor/ link/design-europe). Member States such as Denmark, Estonia, Finland, France and Latvia have also developed action plans for innovation based on design solutions at European level. Fifteen out of twenty eight Member States explicitly identified design as a component of their national innovation strategies. Design, as a driver of innovation, is identified and recognized at the level of local and regional policies, where design is integrated into strategies. Examples include Flanders (Belgium), South Bohemia (Czech Republic), Central Finland, Central Macedonia (Greece), Wales (UK), etc. The involvement of design professionals is also encouraged amongst local authorities such as Lati (France), St. Itano (France), Dublin (Ireland), Katowice (Poland), Kent, Monmouf, Shropshire (UK) (Rutkauskaite, Žeimys, 2016).

Lithuania is one of the few countries that does not have a single institution representing the sector. The Design Innovation Center of the Vilnius Academy of Arts conducted a feasibility study for the development of the design sector and summarized that the faster development of the Lithuanian design sector and the growth of competitiveness require adequate state attention and funding. 2016 During the project "Design for Europe", a design action plan for Lithuania was formulated. However, after delaying the implementation of individual tasks for a certain period of time, it is stated today that we are (and continue to be) a country that does not have a formal design policy.

Design-based thinking can create value and contribute to competitiveness and prosperity, and the European Commission aims to accelerate the uptake of designbased thinking in a wide range of activities at European, national and regional levels by raising awareness. Design allows companies to anticipate consumer expectations and create solutions that provide a competitive advantage. It can lead to rethinking ideas: e.g. change the shape of the product to better meet customer needs, transform website features to be more user-friendly, change the production line to make more efficient use of resources, or simplify processes within the organization to improve results.

According to the European Commission's Innovation Barometer in 2016, $63 \%$ of Lithuanian businesses do not use design solutions at any stage of production (neither in the product stylistics, nor in the processes of its creation or business strategy development). This figure is below the European Union (EU) average, 
where around $50 \%$ of all businesses already integrate design solutions into their operations. In addition, the government's over-emphasis on one sector or another, such as the constant emphasis on individual achievements in the high-tech sector, particularly "discourages" start-ups from innovating in industry or services, and their share of exports is the largest in the total exports of the state. By being able to produce more attractive products using more efficient process solutions and / or more harmonized tools, Lithuanian businesses could be more competitive in the electronic and physical markets in the EU and worldwide.

Lithuanian design is entering a new stage - intersectoral cooperation should be established and consistently developed by the soon-to-be-launched Lithuanian Design Council, which is being established by a joint decision of the Ministries of Culture and Economy and Innovation. It will not only have to make strategic design policy proposals, but also find ways to mobilize the design community to make a significant contribution to the creation of a prosperous Lithuania of the future (Lithuanian Design Sector Coordinating Institution Needs Analysis and Feasibility Study, 2019).

Design as an activity or field, is inextricably linked to the major industrial, technological, economic and social breakthroughs of the new and modern times. Design, which simultaneously means process, process output, and benefit, is one of the most complex modern activities at the intersection of technology and art, production and creation, consumption and culture. As emphasized in the needs analysis of the coordinating institution of the Lithuanian design sector and in the feasibility study (2019), today design stands on the threshold of the fourth industrial revolution as a strategy for thinking and operating future opportunities. In the reality of innovative and technological change, there is a need for new interdisciplinary skills. There is a greater need than ever for skills that would be difficult to automate - social perception, analytical and cognitive, visualization and creative thinking.

\section{Elements and process of design-based thinking}

When the main idea of the design thinking is described, there are four components such as team, process, space and creativity that combine the process into one whole. In the scientific literature, these components are often integrated into the main components, but apart from them, the duality of design-based thinking is clearly disintegrated into already mentioned "thinking" and "acting".

Team is a key feature of design-based thinking is the interdisciplinary approach. Design-based thinking teams are made up of completely different professional backgrounds (Simons, Gupta, Buchanan, 2011). Some studies show that not only is the diversity of professions important to a team, but the personal qualities, learning, and performance styles of each team member are also highly valued (Beckman, Barry, 2007). 
Team members must be open, curious, cooperative and allow them to question their own assumptions and prepare for change. It creates a great team spirit, work ethic and end product.

The process means that all promising ideas must be protected at the beginning of the process, no matter how far they may seem. According to Brown "In contrast to the champions of scientific management at the beginning of the last century, design thinkers know that there is no 'one best way' to move through the process... the reason for the interactive, non-linear nature of the journey is not that design thinkers are disorganized or undisciplined but that design thinking is fundamentally an exploratory process" (Brown 2009, p. 17).

Space should be open to encourage team dialogue. Ideally, a large room with a tall table in the center to allow participants to sit or stand in a circle - thus sitting and standing around the same height - giving people a sense of equality and flexibility.

Creativity is a structured, systematic way of solving problems. Leading a successful organization means being a good problem solver and being creative in the business. If problems can be solved, one can be creative.

Identifying the elements of design-based thinking reveals their interrelationships: in particular, the user-centered reasoning process must involve teamwork, consumers and stakeholders, and a facilitator to assist participants. Second, key outcomes include not only knowledge of the characteristics (such as traits and behaviors) of consumers and stakeholders, but also an understanding of the experiential process, the generation of ideas and concepts. Design-based thinking starts from developing a thorough understanding of customer needs and combine the customer knowledge with employees' creative ideas.

Design-based thinking is not only a way of thinking, but also a way of working that solves a variety of problems through creativity and a variety of approaches, a versatile methodology for solving personal or business issues, precisely when it comes to modern, effective and creative solutions. There seems to be the first attempts developing more elaborated strategies which provide guidelines for managers suggesting how to cultivate creative equity proactively within their organization (Person, Schoormans, 2010). It is difficult to understand design-based thinking because of the dualism that stands out between "thinking" and "acting", and it is therefore necessary to clarify its components.

There are 5 main stages of design-based thinking as a process (Fig. 1):

Empathy plays a key role throughout the process. This component of design-based thinking requires empathy with the client, and the entire design-based thinking process is repeated as many times as it takes to acquire complete knowledge (Vianna, Vianna, Adler, Lucena, Russo, 2012). Having a simple conversation and listening is the best way to know what the client wants and how they are living, how they make their decisions - what the client says and says they do (even if they are different from what they actually do). Physical manifestations of customer 
experiences are captured not only during interviews, but also during observation in relevant contexts, e.g. their relation to the environment allows to decide the intangible meaning of those experiences, which enables to reveal insights. These insights help to create innovative solutions, because empathy is what helps to see phenomena differently in the distance.

Identification (definition) is an important statement about a problem, helping the team and focusing on the specific needs revealed. "The only way to create the right solution is by 'framing' the right problem" (Brown, 2008). This phase aims to give meaning to the information that has already been gathered, based on customer knowledge and context, and begins to form a point-of-view. It is a guiding statement that focuses on the insights and needs of a particular user. In the identification phase, the inferred conclusions focus on insights - this work synthesis offers an advantage no one else has: insights used to solve a challenge are intuitive, and the resulting solution is considered creative, fluent and open, and also looking for a better future.

Ideating is a technique of "stepping out of your comfort zone" to create prototypes of an idea that reflects services or experiences (Wattanasupachoke, 2012). This is not about coming up with the "right" idea, but about generating the broadest possible opportunities. According to Baeck and Gremett (2011), design-based thinking focuses on the development (at least in the early stages of the process). Ideating is the possibility to combine existing understanding of the problem area and the customer for whom this is being created with the imagination of the designer in order to create concepts for the solution. This reduces the fear of failure and maximizes the contribution to the idea generation phase. Brainstorming sequence: overlooking obvious solutions, thus increasing the potential for innovation, creating fluency (for scope) and flexibility (for diversity) in new choices, drawing on the strengths of the creative team.

Prototyping is also known as "thinking by hands" (Vianna et al., 2012), which allows us to apply the best solutions derived from ideas and present them to the user whose problem is solved. In order not to lose the full innovation potential generated by the ideation, it is necessary to use the process of deliberate selection, where prototypes are created for two or three ideas that have received the most support from the creative team. It preserves the potential for innovation - a radically different approach to one idea. Prototypes are also artefacts of iterations that can give answers to questions and in that way bring you closer to the final solution. Opportunities are also tested with fewer resources for each idea - less time and money invested in advance. Many different ideas can be implemented to maintain low resolution without going into the direction too early. In controlling the decision-making process, variable identification encourages the breakdown of the underlying problem into smaller, testable parts. 
Testing is often done in conjunction with prototyping. The process focuses on the prototype and the context in which the test is conducted, user interaction and feedback. Early testing ensures that no time is wasted on refining and sticking to one idea and considering who and how will be tested before creating a prototype. Examining these two modes together gives rise to two layers of prototype testing: although prototyping and testing are sometimes completely intertwined, planning and executing a successful test scenario is often a big additional step in creating a prototype because it is not simply presented to the user for simple testing. Often, the most informative results are the result of a detailed reflection on how testing is to be conducted in order to obtain the most natural and honest user feedback. Testing is another way to understand your user, but unlike the initial mode of empathy, at this stage, more "problem framing" and test prototypes are produced for testing. The prototype is always built as if it is known in advance that it is correct, but it is tested as if it is known in advance that it is wrong. According to Thoring and Muller (2011) this creates an opportunity for improvement of solutions and prototypes. Iteration is the basis of good design-based thinking. In general, as design-based thinking goes through several cycles - the scope narrows and shifts from a broad concept to nuanced details, and the process, in this case, still supports development.

Martin (2009) argues that it is not worth stopping at the testing principle because often a by-product of a design-based thinking process is the generation of other unique ideas that can go hand in hand with an ongoing goal or lead to finding ways to develop a strategy.

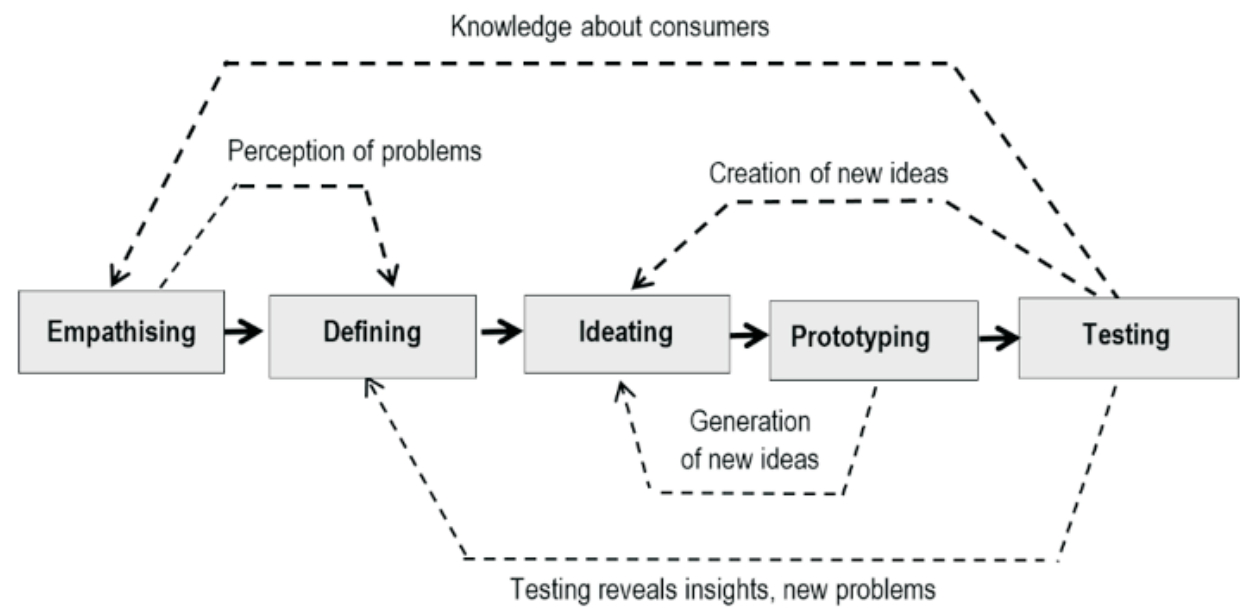

Fig. 1. Stages of the design based thinking method as a process

Source: Adapted from: Brown, 2008; Thoring, Muller, 2011 


\section{Possibilities of application of design-based thinking method in business operations}

In the context of globalization, the rapid development of technology, the increasing use of innovation, the geographical expansion of markets, the increase in consumption, when the consumer has the greatest choice, and the depletion of resources, companies are under great competitive pressure. It is becoming an increasing challenge for a business to provide long-term value to its customers in the future. Companies constantly analyse the actions of competitors, consumer needs and look for market development opportunities in order to form a competitive advantage. Design is one of the most versatile activities - it is difficult to imagine an area of life in which it would not work.

"A strong design sector not only affects the quality of life, promotes economic growth and increases the country's competitiveness, but also helps to solve social problems and model a more sustainable future. In prosperous countries, the design sector is given special attention. By supporting and strengthening this sector, it becomes a reliable partner in creating a sustainable economy and creatively meeting the challenges of the future" (Needs Analysis and Feasibility Study of the Coordinating Institution of the Lithuanian Design Sector, 2019, p. 4).

Further explanations of Martin (2009) is how design-based thinking can be used in business strategy "Design thinking is the form of thought that enables movement along the knowledge funnel, and the firms that master it will gain an inexhaustible, long-term business advantage. The advantage, which emerges from the design-thinking firms' unwavering focus on the creative design of systems, will eventually extend to the wider world. From these firms will emerge the breakthroughs that move the world forward [because] design-thinking firms stand apart in their willingness to engage in the task of continuously redesigning their business."

Design-based thinking requires constant courage, which must begin at the strategic level and move to the executive and implementation levels. Applying a design-minded approach to thinking helps to create new solutions, and can be a great tool for business creation and improvement, as it can change people's attitudes towards what they do, encourages creativity and change. Therefore, it can be argued that Design-Based Thinking helps organizations to create an organizational culture and shape an environment that fosters new ideas and creative solutions by involving all stakeholders in the generation of ideas. However, applying this method is not the only and best way to develop a business, it also has its drawbacks, such as the risk of stakeholder involvement, the assessment of investment and their return on development of a new product or improvement of an existing one. Therefore, it can be argued that a design-based thinking approach does not solve all problems, but can be a great tool to help model the value proposition to the user and identify gaps in business management processes. 


\section{Conclusions}

Based on the analysis of scientific literature, the following conclusions can be drawn:

1. Design-based thinking is perceived as means of creating added value by using the company's available resources and improving processes at all levels of the company. Design-based thinking is also seen as a key tool for identifying problems by exploring consumer and business problems through its elements and principles. Academically designed based thinking can be seen as a methodology for analyzing concepts and ideas.

2. Design-based thinking is recommended to use the $\mathrm{EU}$ as a tool for the formation of competitive advantage, unfortunately in Lithuania it is not widely used as a basis for strategy development and organizational change in shaping a culture focused on problem solving.

3. Design-based thinking involves teams including stakeholders, such as designers, business and consumers, with their opinions, experiences, competencies and suggestions that transform new challenges and value-added solutions in a solution process that challenges an environment of openness and creativity. In the process of design-based thinking, skills and abilities are singled out as valuable resources. The application of visualization at a certain stage of the process provides an opportunity to more clearly identify the expected results, and prototyping and testing reduces the likelihood of failure, neutralizes the negative impact, saves money, preserves the company's image.

4. Design-based thinking can give a company a competitive advantage and help to solve business model challenges and find non-traditional solutions, but the application of this model is not limited only to the business environment. The importance and necessity of improving the educational process can benefit from integrating new and inclusive didactic methods and develop learners' critical thinking, creativity, cooperation, decision-making, etc. These competencies are identified by the World Economic Forum (2016) as one of the most important competencies that every young person should have in order to integrate into the modern labor market. This poses considerable challenges for educators, who should "believe" in a philosophy of teaching and learning in line with modern educational trends, and the educational process they should focus not only on the provision of basic knowledge, but also on the development of these competencies using new didactic methods and techniques such as design-based thinking. 


\section{REFERENCES}

[1] Baeck, A., Gremett, P., 2011. Design Thinking, [In:] H. Degen, X. Yuan (Eds.), UX Best Practices - How to Achieve More Impact with User Experience, McGraw-Hill Osborne Media.

[2] Beckman, S.L., Barry, M., 2007. Embedding Design Thinking, California Management Review, Vol. 50, No. 1.

[3] Brown, T., 2008. Definitions of design thinking, Harvard Business Review, June.

[4] Brown, T., 2009. Change by Design: How Design Thinking Transforms Organizations and Inspires Innovation, Harper Business, New York.

[5] Cohen, R., 2014. Design Thinking: A Unified Framework for Innovation. Forbes, March 31.

[6] Heskett, J., Dilnot, C., Boztepe, S., 2017. Design and the Creation of Value, Bloomsbury Academic, New York.

[7] Johansson-Solberg, U., 2013. Design Thinking: Past, Present and Possible Futures, Special Issue on Design Management, John Wiley \& Sons Ltd., Vol. 22, No. 2.

[8] Krippendorff, K., 2006. The Semantic Turn: A New Foundation for Design, Routledge.

[9] Liedka, J., King, A., Bennet, K., 2013. Solving Problems with Design Thinking, Columbia University Press.

[10] Lithuanian Design Sector Coordinating Institution Needs Analysis and Feasibility Study: Lietuvos dizaino sektoriu koordinuojančios institucijos poreikio analizè ir galimybiu studija, 2019, https:// issuu.com/dizainosavaite/docs/galimybiu_studija (access: 16.11.2020).

[11] Martin, R., 2009. The Design of Business: Why Design Thinking is the Next Competitive Advantage, Harvard Business School, Cambridge.

[12] Owen, C., 2007. Design thinking: Notes on its nature and use, Design Research Quarterly, No. 2(1).

[13] Person, O., Schoormans, J., 2010. Cultivating creative equity in Scandinavian design brands, Design Issues, No. 26(4).

[14] Rutkauskaité, G., Žeimys, P., 2016. Ar dizainas vertas Europos investicijų? Dizaino sprendimais paremtu inovaciju ekosistemos Europoje analizè Jungtine Karalystè/Danija/Estija, http://kurklt. lt/wp-content/uploads/2016/12/U\%C5\%BEsienio-\%C5\%A1ali\%C5\%B3-analiz\%C4\%97-2016. pdf (access: 16.11.2020).

[15] Schmiedgen, J., Rhinow, H., Köppen, E., Meinel, C., 2015. Parts Without a Whole? - The Current State of Design Thinking Practice in Organizations, Hasso-Plattner-Institut für Softwaresystemtechnik an der Universität Potsdam, Potsdam.

[16] Simon, H.A., 1969. The Sciences of the Artificial, MIT Press, Cambridge.

[17] Simons, T., Gupta, A., Buchanan, M., 2011. Innovation in R\&D: Using design thinking to develop new models of inventiveness, productivity and collaboration, Journal of Commercial Biotechnology, No. 17.

[18] Thoring, K., Müller, R.M., 2011. Understanding design thinking: a process model based on method engineering. International Conference on Engineering and product design, UK, London, https://www.researchgate.net/publication/234065413_Understanding_design_thinking_A_process_model_based_on_method_engineering\#fullTextFileContent (access: 16.11.2020).

[19] Vianna, M., Vianna, Y., Adler, I.K., Lucena, B., Russo, B., 2012. Design thinking. Business innovation, MJV PRESS, Rio de Janeiro.

[20] Wattanasupachoke, T., 2012. Design Thinking, Innovativeness and Performance: An Empirical Examination, International Journal of Management and Innovation, Vol. 4, No. 1. 